\title{
The Impact of International Logistics to International Trade Research Based on an Empirical Analysis of the Data in 1995-2014 in Shandong Province
}

\author{
Zhenyu Jiang ${ }^{1}$ and Yaohua $\mathrm{Wu}^{1}$ \\ ${ }^{1}$ Modern Logistics Institute, Shandong University, China
}

\begin{abstract}
By using time series model, this paper uses the data of Shandong province GDP, total value of import and export, the port cargo throughput and traffic volume from 1995 to 2014 in Shandong province, and empirical research on Shandong international logistics and international trade relations is based on the cointegration theory and Granger Causality Test. The empirical results show that the relationship has been longterm stable co-integration, and the one-way causation is between the port cargo throughput, traffic volume and the total amount of import and export, and deduced guiding mechanism of international logistics to international trade. So government ought to pay attention to strengthen international logistics influence to international trade, and complete open trade policy, strengthen the logistics personnel training, increase the intensity of port infrastructure construction, accelerate the process of bonded area logistics system.
\end{abstract}

\section{Introduction}

With the advent of modern times, international trade globalization and transport logistics integration have already become general direction and an important theme of the development of world economy. Also the development of the logistics industry has gained more and more support and attention, not only because it is a kind of advanced management technique or a way of organization on its own, but also it has gradually become an important index to measure the whole national comprehensive power and level of modernization. With the in-depth development of the reform and opening, and the increasingly rapid tendency of the economic globalization and trade internationalization, international trade, which is as the close tie between China and the rest of the world, has created a certain effect on the economic development of China and the world and also becomes a core and focus of the world economic competition, subtly affecting a country's world status and economic pattern. Joint development of the international logistics and international trade is both a kind of development status and a requirement in our own time. Many countries have realized international commercial trade and international business services through economic globalization and the integration of information technology to pursue the economic benefit maximization and efficiency of international trade market.

In recent years, Shandong province attaches great importance to the development of international trade, especially international logistics, both offering huge investment and cultivation, either in the construction of logistics infrastructure or in the logistics technical innovation. Also Shandong province has obtained some results in constantly consummating the logistics infrastructure, pushing forward the marketed-based logistics process and the electronization of logistics industry. Since the fully implement of five-year plan for 2011 to 2015, the reform of Shandong province's international trade has rapidly developed, adjusting structure, changing economic increasing methods and growing steadily, which also makes some achievements. In 2011, Shandong province's total volume of import and export breaks the barrier of 200 billion dollars at first time, totaling \$235.87 billion, with year-on-year growth of 24.7 percent, hailing it as a "milestone" for the international trade of Shandong province. At the same time, Shandong province, whose international logistics industry maintains its stable and fast growth, is one of the China's developed provinces of trade. Since "Twelve Five-Year" plan, the logistics market of Shandong province is growing continuously. And this amount accounts for 6.5 percent of regional GDP and for 14.9 percent of proportion of the third industry. Its steady growth model protects the development of the international trade of Shandong province, playing an vital role in the support and safeguard. And with more and more attention payed on the logistics industry, Shandong province has made great progress either in the infrastructure construction and Industrial linkage development or in the process of international trade and logistics information development. During the "Twelfth Five-year Plan" period, logistics enterprises in Shandong province has reached more than 22000, among which there are 836 key enterprises. There are 339 
logistics parks in Shandong province, whose development not only promotes the social employment and strengthens the social security, but also boosts the regional economic development and promotes the scale effect. Shandong province has increased production berths of coastal ports to 540 , and open 8 civil aviation and 368 air routes, among which there are 41 international flights, primarily establishing the framework of the international trade of Shandong province.Modern information technology, such as Internet and cloud computing gradually start to apply in the international trade and economy of circulation. Most of international logistics enterprises have established logistics information management system and determine the information of transportation, warehousing and forwarding of international goods by real-time controlling. And they promote the construction of logistics information sharing platform while they also perfect the standardization of international logistics, setting 49 standards for logistics successively, which exerts an enormous influence on the development of Shandong province's logistics. Thus it can be seen that the international trade and logistics in Shandong province, which is one of the China's developed province of trade, are developing in coordination. Driven by the national strategy Blue Economic Zone of Shandong Peninsula, the international logistics' demand and standard of Shandong province will get more improvement and more progress.

No matter from the development status of international trade and international logistics or the support of policy, it embodies the attention of our country paid to the both aspects. China's logistics industry after more than 30 years of reform, release and accumulation, is striding forward towards modernization, intensification, standardization and the investment in logistics infrastructure and the logistics efficiency is getting better and better, so the research for international trade and international logistics is valuable for theory and practice. But believe it or not, there are some problems in the development of international business and international logistics in China, such as high costs of logistics, insufficiency in logistics demand, unreasonable network layout, and imperfect technology standards and so on. So China's logistics industry must keep updating and innovating, realizing the service ability, improving the efficiency, in order to adapt to the rapid development of international business and lay a solid foundation for development of international business.

\section{Literature review}

Logistics, originated in western countries, is a highlydeveloped discipline in terms of its scope, process and methods. The studies conducted in this field are comprehensive and detailed with advanced approaches. However, the case is different in China. In fact, the concept was recently introduced and did not receive enough attentions until the globalisation has shown its irresistance. As a result, certain challenges still wait to beconquered. Yet the theoretical researches did achieve abundant results and provided a solid foundation for this article.

\subsection{Relationship between international logistics and international trade}

The International logistics and international trade are of inseparable and complementary relationship. The former is emerged due to the prosperity of international trade while it now pushes the latter into a better future. This relationship reflects their mutual support and influences during interaction. Besides, the concepts of low-carbon economy and environmental logistics also contribute to tightening these two fields and turning them into the new normal of economic growth after the financial crisis based on the theory of sustainable development [1]. Consequently, increasing number of experts and scholars at home and abroad have dedicated themselves to the empirical study of international logistics and international trade, some of which studied the data of bilateral trade and international logistics between China and Australia. The results showed that the bilateral trade has a positive and noticeable influence on the development of the international logistics. However, the influence is not significant due to the late start and slow process of logistics in China. Further studies analysed cases of international trade between Australia and other countries, such as China, America, Japan, etc., by VAR model. Besides, Tongzon (2009) recognised the accelerator role international trade has played in the development of international logistics industry [2]. Still, Nguyen and Tongzon (2009) also found the lack of infrastructure and investment causes the lagging growth of logistics and failed to promote the international trade [3]. While in China, experts at first also used Ganger Causality Test to examine this relationship by the volume of seaborne trade and the statistics of import and export between China and Europe, North America and Japan from 1983 to 2004. Yang (2007) proved the existence of strong feedback and causalityin international logistics and international trade [4]. Zhang (2011) explored the same phenomenonby taking the bilateral trade and cargo throughput between China and Thailand into consideration. Their conclusion is that certain interaction between international trade and logistics do exist in China-Thailand trade yet the promotion from international trade to international logistics are more significant than the other way around [5]. Same result has been reached by the appliance of logisticsin modelling analysis. The scientific modelling of Yue (2013) in empirical study of the total volume of international trade and cargo volume of China and Japanese from 1994 to 2011 demonstrated that the development of international logistics did encourage the business interaction. However, it pointed out that the future boost of international logistics has to rely on innovation instead of pure expansion [6]. Besides, appreciable achievements can be noticed based on data collected from provincial level. Taking the total value of international logistics as the reflection of its development state, Wang and Liu (2014) conducted empirical studies on the data of international trade and logistics in Tianjin municipality, which indicated a notable Ganger Causality and a long-term balance between the total value of international logistics and the trade volume of exportation and importation [7]. On top of that, similar conclusions 
have also been reached in Wang's study analysing the volume of cargo traffic, port throughput and import and export in Shanghai from 1978 to 2008. The co-integration relationship among the three variables can be further explained as the following three aspects by Wang (2010): the trade value of import and export shows a positive effect onthe port throughput; no clear contribution is made when the value of throughput increased; and the value of cargo traffic has a time-leg effect on the trade value of import and export [8]. Their findings revealed the onesidedness of expanding the construction and coverage of logisticsparks and provided suggestions on using innovative method to conduct a deep reform of the logistics industry. Furthermore, Wang and Wang (2011), and Gao and Meng (2012) arrived at the same conclusion with statistics from Taiwan and Guangdong province, respectively, proposing a significant influence of international logistics on international trade in a stable and lasting relationship while little from international trade to international logistics [9-10].

\subsection{The influence of international logistics on international trade}

The International trade and international logistics has mutual influence in the developing process. In other words, a strong relevancy can be recognised in these two fields. Therefore, a large number of experts and scholars carry on studies of theinfluential mechanism and factors focusing on logistics efficiency, costs, etc. It aims to produce more powerful momentum of international logistics for international trade through decreasing logistics costs, increasing service standard, improving profits and adding commercial value. Kong (2010) applied the impulse response function of VAR model on the time series data between 2002 and 2008 to launch a quantitate analysis. The result illustrated that the development of international logistics in China has generate a significant positive influence on international trade [11]. More particularly, Devlin and Yee (2002) took specific trade in the MiddleEast and North Africa (such as tuna and coffee in Yemen) as research samples to conduct empirical studies on time cost which is an important section of international trade cost. As the results demonstrated, the international logistics efficiency affects the international trade level through the impact on the time costs [12]. Also, the analysis and evaluation of international trade behaviour and logistics level between America and Canada provided evidence for the promotion of international logistics efficiency by decreasing the logistics costs by Keane and Feinberg (2007). This phenomenon facilitated the trade and economic benefits of the two countries and accelerated the overall development of international trade [13]. Detailed analysis was conducted by Nordas et al. (2006) as well [14]. They adopted the international trade statistics of 191 countries and found out how exactly international logistics and international trade influenced each other. The result illustrated that the decrease of time cost is achieved by raising logistics efficiency in international trade. Besides, they noticed the inverse relation between time costs and the possibility of trading, in which the lower the cost becomes, the higher the possibility would be Additionally, the possibility of international trade can promote logistics industry domestically and internationally. In this area, Li (2012) analysed data of international trade and logistics from 108 countries and proposed six main factors that influence the international logistics development on the national basis, which are customs efficiency, infrastructure, international shipping, service quality, the ability to track cargos, and punctuality [15]. Conforming to Li's findings, different factors affect the development of international logistics on different levels and there is clear existence of a positive relation between international trade and logistics. In terms of specific area in China, Chen (2007) conducted a modelling analysis of the relationship between the international trade and logistics in Shanghai [16]. The measurement result illustrates a parallel growth in international trade and logistics. Yet through the data of throughput and logistic growth curve, the international logistics has a clear motivation to international trade. Other researches such as $\mathrm{Li}$ and Sun (2013) creating modelling using statistics of Yunan province from 1981 to 2010 pointed out the stable Ganger causality on a long-term basis between international trade and logistics. Only the influence of logistics on international trade is more significant [17].

\section{The empirical study of the relationship between the international logistics and trade in Shandong province}

\subsection{Selection for data index and data processing}

Before the empirical analysis for correlation between the international logistics and international trade, we need to choose proper variables for the data description and the model building. At first, this paper select GDP as the index to measure economic development level; secondly, the gross import and export value (XM) is chosen as the index to measure the international trade level. Thirdly, for the reason that there lacks unified measure in the international logistics, to better reflect the relationship between the international logistics and international trade, this paper select cargo throughput(TTL) and cargo transportation(YSL)as the index to measure the international logistics.

The data in this paper are from China Statistical Yearbook and Shandong Statistical Yearbook, intercepting the gross domestic product (GDP), total export-import volume (XM), cargo throughput (TTL) and cargo throughput (YSL)in Shandong province from 1995 to 2014. By taking logarithm of GDP, XM, TTL and YSL to eliminate the possible heteroscedasticity, the results as follow: $\operatorname{lnGDP}, \operatorname{lnXM}, \operatorname{lnTTL}$ and $\operatorname{lnYSL}$. The results are in the Table I .

Table 1. Sample data

\begin{tabular}{|c|c|c|c|c|}
\hline Obs. & LNGDP & LNXM & LNTTL & LNYSL \\
\hline 1995 & 8.507819 & 14.148410 & 11.570628 & 11.105649 \\
\hline
\end{tabular}




\begin{tabular}{|l|l|l|l|l|}
\hline 1996 & 8.679958 & 14.295708 & 11.701941 & 11.165692 \\
\hline 1997 & 8.785244 & 14.377199 & 11.819336 & 11.195196 \\
\hline 1998 & 8.856711 & 14.323376 & 11.810323 & 11.249129 \\
\hline 1999 & 8.921837 & 14.418237 & 11.843365 & 11.292428 \\
\hline 2000 & 9.028515 & 14.731400 & 11.984484 & 11.434780 \\
\hline 2001 & 9.126419 & 14.878949 & 12.170342 & 11.507551 \\
\hline 2002 & 9.237518 & 15.037571 & 12.303018 & 11.584818 \\
\hline 2003 & 9.399153 & 15.311948 & 12.452503 & 11.675996 \\
\hline 2004 & 9.617260 & 15.620209 & 12.629640 & 11.790830 \\
\hline 2005 & 9.818304 & 15.855285 & 12.858424 & 11.904961 \\
\hline 2006 & 9.994251 & 16.069831 & 13.060616 & 12.028804 \\
\hline 2007 & 10.157234 & 16.321999 & 13.262946 & 12.198580 \\
\hline 2008 & 10.339588 & 16.576437 & 13.396799 & 12.419121 \\
\hline 2009 & 10.431071 & 16.444545 & 13.501786 & 12.558358 \\
\hline 2010 & 10.575664 & 16.754412 & 13.669571 & 12.605033 \\
\hline 2011 & 10.722427 & 16.976723 & 13.776645 & 12.660207 \\
\hline 2012 & 10.820043 & 17.016405 & 13.879943 & 12.707666 \\
\hline 2013 & 10.919267 & 17.100768 & 13.982185 & 12.749562 \\
\hline 2014 & 10.992497 & 17.137360 & 14.066993 & 12.472209 \\
\hline Sourse:China StatisticalYearbok and Shandong Statistica1Yerbook
\end{tabular}

Sourse:China Statistical Yearbook and Shandong Statistical Yearbook.

\subsection{Data dependence analysis}

This paper regards the correlation coefficient among the 4 variables, which is through complex computing, as the evaluation standard to distinguish the correlation and its degree by means of Eviews8.0 to get the correlation coefficient. The results are in the Table II. It can be seen from the data that the variables are almost positively related to each other. So conclutions show that there may be a certain correlation among the 4 variables.

Table 2. Correlation among GDP,XM,TTL and YSL

\begin{tabular}{|c|c|c|c|c|}
\hline & LNGDP & LNXM & LNTTL & LNYSL \\
\hline LNGDP & 1.0000 & 0.9955 & 0.9990 & 0.9869 \\
\hline LNXM & 0.9955 & 1.0000 & 0.9969 & 0.9867 \\
\hline LNTTL & 0.9990 & 0.9969 & 1.0000 & 0.9873 \\
\hline LNYSL & 0.9869 & 0.9867 & 0.9873 & 1.0000 \\
\hline
\end{tabular}

It is obvious that the correlation coefficients among gross domestic product (LNGDP), total export-import volume (LNXM), cargo throughput (LNTTL)and cargo throughput (LNYSL) are more than 0.9850 , which means there are significantly correlated with each other.

\subsection{The test of data stability}

Through the test of correlation from data dependence analysis, it can be concluded that there are a significantly positive correlation among the 4 variables in some degree. However, there is another kind of possibility in the factual economic situation, that is there may be no correlation in theory between two or among several variables, just because some kind of economic phenomenon leading to the same correlation among 4 variables. Therefore, the illusion of the correlation has shown up, which is so called spurious regression. So in order to discuss the relationship between the international trade and the international logistics, this paper will give experimental variables stationary test and then the Granger Causality Test.

This paper will make use of ADF unit-root test to implement the stationary test, that is by using Eviews 8.0 to take the Augmented Dickey-Fuller test on the gross domestic product (GDP), total export-import volume (XM),cargo throughput (TTL) and cargo throughput (YSL)in Shandong province and difference sequence. The results are as follows in the Table III.

Table 3. ADF test results

\begin{tabular}{|c|c|c|c|c|c|c|}
\hline \multirow{2}{*}{ Variables } & \multirow{2}{*}{$\begin{array}{c}\text { ADF } \\
\text { statistical } \\
\text { value }\end{array}$} & \multirow{2}{*}{$\begin{array}{c}\text { Data test } \\
\text { type } \\
(\mathrm{c}, \mathrm{t}, \mathrm{q})\end{array}$} & \multicolumn{3}{|c|}{ Critical Value } & \multirow{2}{*}{ Prob.* } \\
\hline & & & $1 \%$ & $5 \%$ & $10 \%$ & \\
\hline Ln(DGP) & -3.007936 & $(\mathrm{c}, \mathrm{t}, 1)$ & -4.571559 & -3.690814 & -3.286909 & 0.1568 \\
\hline $\mathrm{D}(\mathrm{lnDGP})$ & -4.411935 & $(\mathrm{c}, \mathrm{t}, \mathrm{3})$ & -4.616209 & -3.710482 & -3.297799 & 0.0145 \\
\hline $\operatorname{Ln}(\mathrm{XM})$ & -1.617651 & $(\mathrm{c}, \mathrm{t}, 1)$ & -4.532598 & -3.673616 & -3.277364 & 0.7469 \\
\hline $\mathrm{D}(\ln \mathrm{XM})$ & -3.687115 & $(\mathrm{c}, 0,0)$ & -3.857386 & -3.040391 & -2.660551 & 0.0141 \\
\hline $\operatorname{Ln}(\mathrm{TTL})$ & -2.849741 & $(\mathrm{c}, \mathrm{t}, 1)$ & -4.571559 & -3.690814 & -3.286909 & 0.1995 \\
\hline $\mathrm{D}(\operatorname{lnTTL})$ & -3.815301 & $(\mathrm{c}, \mathrm{t}, 0)$ & -4.616209 & -3.710482 & -3.297799 & 0.0417 \\
\hline $\operatorname{Ln}(\mathrm{YSL})$ & -1.500834 & $(\mathrm{c}, \mathrm{t}, 1)$ & -4.571559 & -3.690814 & -3.286909 & 0.7906 \\
\hline $\mathrm{D}(\ln Y S L)$ & -4.533857 & $(\mathrm{c}, \mathrm{t}, 0)$ & -4.616209 & -3.710482 & -3.297799 & 0.0116 \\
\hline
\end{tabular}

D: first difference; c: intercept; t: time trend; q: lag order.

By results of ADF test, when significance level is 0.05 , the $\ln (\mathrm{GDP}), \ln (\mathrm{XM}), \ln (\mathrm{TTL})$ and $\ln (\mathrm{YSL})$ are all non stationary series, but after first difference, they are all stationary series under the same significance level, which fully indicate that $\ln (\mathrm{GDP}), \ln (\mathrm{XM}), \ln (\mathrm{TTL})$ and $\ln (\mathrm{YSL})$ are all integrated of order one.

\subsection{The test of Co-integration relationship}

Granger and Engel once put it forward in the 1987 that if there were at least two time series which were non stationary but their linear combination was stationary, it mean that there was a co-integration relationship among the sequences. Through the ADF test results from data stability test showing the conditions that the four time sequences $\ln (\mathrm{GDP}), \ln (\mathrm{XM}), \ln (\mathrm{TTL})$ and $\ln (\mathrm{YSL})$ meet. This paper will take VAR co-integration relationship test on the sequences above. Johansen trace approach is used to test the number of integration relationship, and the results are in the Table IV.

Table 4. Johansen trace test

\begin{tabular}{|c|c|c|c|c|}
\hline \multicolumn{5}{|c|}{ Unrestricted Co-integration Rank Test (Trace) } \\
\hline Hypothesized & & Trace & 0.05 & \\
\hline No. of CE(s) & Eigenvalue & Statistic & Critical & Prob.** \\
\hline None $*$ & 0.957950 & 79.10161 & 47.85613 & 0.0000 \\
\hline At most 1 & 0.591453 & 28.39934 & 29.79707 & 0.0718 \\
\hline At most 2 & 0.470111 & 14.07696 & 15.49471 & 0.0808 \\
\hline At most 3* & 0.217078 & 3.915553 & 3.841466 & 0.0478 \\
\hline Trace test indicates 1 co-integrating eqn(s) at the 0.05 level \\
\hline \multicolumn{5}{|c|}{ * denotes rejection of the hypothesis at the 0.05 level } \\
\hline **MacKinnon-Haug-Michelis (1999) p-values \\
\hline
\end{tabular}


Table IV shows that there are two Co-integration equation among the four variables, $\ln (\mathrm{GDP}), \ln (\mathrm{XM})$, $\ln (\mathrm{TTL})$ and $\ln (\mathrm{YSL})$, the conclusion is that there are cointegration relationship among the variables.

\subsection{The test of Granger causality}

This research employs a lagged variable into other equation, and the Granger relationship exists when the variable in equation is affected by the lagged one. Using command Granger causality test from Eviews8.0, the model tests the causality of $\ln (\mathrm{GDP}), \ln (\mathrm{XM}), \ln (\mathrm{TTL})$ and $\ln (\mathrm{YSL})$ to see if the Granger causality exist.

Table 5. Granger causality test.

\begin{tabular}{|c|c|c|c|c|}
\hline Null Hypothesis: & Obs & F-Statistic & Prob. & Conclusion \\
\hline \multirow{3}{*}{$\begin{array}{l}\text { (1)LNTTL does } \\
\text { not Granger } \\
\text { Cause LNGDP }\end{array}$} & 19 & 4.63062 & 0.0470 & Reject \\
\hline & 18 & 0.00535 & 0.9426 & Accept \\
\hline & 17 & 1.06977 & 0.4051 & Accept \\
\hline \multirow{3}{*}{$\begin{array}{l}\text { (2) LNTTL does } \\
\text { not Granger } \\
\text { Cause LNXM }\end{array}$} & 19 & 0.02311 & 0.8811 & Accept \\
\hline & 18 & 0.93444 & 0.4177 & Accept \\
\hline & 17 & 0.91445 & 0.4684 & Accept \\
\hline \multirow{3}{*}{$\begin{array}{l}\text { (3) LNXM does } \\
\text { not Granger } \\
\text { Cause LNGDP }\end{array}$} & 19 & 10.6389 & 0.0049 & Reject \\
\hline & 18 & 0.31014 & 0.7386 & Accept \\
\hline & 17 & 0.60058 & 0.6292 & Accept \\
\hline \multirow{3}{*}{$\begin{array}{l}\text { (4) LNGDP does } \\
\text { not Granger } \\
\text { Cause LNXM }\end{array}$} & 19 & 4.7E-06 & 0.9983 & Accept \\
\hline & 18 & 0.03301 & 0.9676 & Accept \\
\hline & 17 & 0.17485 & 0.9110 & Accept \\
\hline \multirow{3}{*}{$\begin{array}{l}\text { (5)LNXM does } \\
\text { not Granger } \\
\text { Cause LNTTL }\end{array}$} & 19 & 7.78327 & 0.0131 & Reject \\
\hline & 18 & 1.13336 & 0.3518 & Accept \\
\hline & 17 & 1.56248 & 0.2590 & Accept \\
\hline \multirow{3}{*}{$\begin{array}{l}\text { 6) LNXM does } \\
\text { not Granger } \\
\text { Cause LNYSL }\end{array}$} & 19 & 9.33627 & 0.0076 & Reject \\
\hline & 18 & 3.03615 & 0.0828 & Reject \\
\hline & 17 & 3.54048 & 0.0560 & Reject \\
\hline \multirow{3}{*}{$\begin{array}{l}\text { (7) LNYSL does } \\
\text { not Granger } \\
\text { Cause LNXM }\end{array}$} & 19 & 0.00535 & 0.9426 & Accept \\
\hline & 18 & 0.01526 & 0.9849 & Accept \\
\hline & 17 & 0.51472 & 0.6813 & Accept \\
\hline \multirow{3}{*}{$\begin{array}{l}\text { (8) LNGDP does } \\
\text { not Granger } \\
\text { Cause LNYSL }\end{array}$} & 19 & 2.62531 & 0.1247 & Accept \\
\hline & 18 & 3.39637 & 0.0651 & Reject \\
\hline & 17 & 2.85079 & 0.0912 & Reject \\
\hline \multirow{3}{*}{$\begin{array}{l}\text { (2)LNTTL does } \\
\text { not Granger } \\
\text { Cause LNXM }\end{array}$} & 19 & 0.02311 & 0.8811 & Accept \\
\hline & 18 & 0.93444 & 0.4177 & Accept \\
\hline & 17 & 0.91445 & 0.4684 & Accept \\
\hline
\end{tabular}

Results show in TableVI:on the assumption of $10 \%$ significance level, Empirical results of hypothesis include (1)LNTTL does not Granger Cause LNGDP and(2)LNXM does not Granger Cause and the LNGDP indicate that with a lag phase the total amount of import and export cargo throughput is the Granger reason of GDP. But in the lags of two and three phases this Granger causality does not exist.

In addition, the null hypothesis can be accepted under the $10 \%$ significant level that the cargo throughput and the gross domestic product is not the Granger reason of the total amount of imports. Conclusion can be tested from one and three phase lagged hypothesis including (2) LNTTL does not Granger Cause LNXM and (4)LNGDP does not Granger Cause LNXM.

Through the comparison of(5)LNXM does not Granger Cause LNTTL and (6) LNXM does not Granger Cause LNYSL, concluding that import and export are always the Granger reason of freight volume growth, it is also the lagged Granger reason of cargo throughput growth, which shows a one-way causal relationship between the amount of cargo transport, cargo throughput and the total amount of import and export. Namely, the development of the total import and export together with import and export growth will accelerate cargo transportation volume and cargo throughput of Shandong province in the long term. However, this promoting effect is not obvious between the amount of cargo transport, cargo throughput and the total import and export trade growth in Shandong Province.

Finally, test results of hypothesis (3)LNXM does not Granger Cause LNGDP and (8)LNGDP does not Granger Cause LNYSL show that in one phase lag, the total amount of import and export is the Granger reason of GDP, and in the two period lag, domestic product is the Granger reason of freight volume of Shandong Province. Therefore, causality of the total amount of import and export in addition to the domestic product and the total freight volume both have certain time-lag effect and even longer effect of the latter.

\section{Conclusions and policy suggestions}

\subsection{Conclusions}

Relying on the results of above empirical analysis, this paper summarized relevant main conclusions as follows.

Firstly, seen from a long-term, there is a long-term equilibrium relationship between economic development and international trade, international logistics in Shandong province. The respective time series of gross regional production, total export-import volume, freight traffic volume and cargo handling capacity are all non-stationary series. But after the first order difference, these four variables are stationary time series, thus indicating they are all one-order integrated series essentially that the longterm co-integration relationship exists among all data.

Secondly, the total export-import volume has a oneway causal relation to freight traffic volume and cargo handling capacity that shows the increase of total amount of international trade in Shandong province will corresponding promote the development of international logistics in the province and improve the benefits of international logistics. However, the development of international logistics in Shandong province has a relatively weak impact on international trade. 
Thirdly, the analysis results show that total exportimport volume is the Granger-cause of gross regional production in the condition of lag phase I, and the gross regional production in Shandong province is the Grangercause of freight traffic volume in lag phase II. Therefore, the effect of gross regional production on total exportimport volume and the impact of gross regional production on freight traffic volume have certain hysteresis effect, and the latter's lagging effect longer. In other words, in the long-term, the increase of international trade in Shandong province will drive growth of gross regional production which in turn drives growth of international logistics yield in Shandong province. This well confirmed that there is a permanently interconnected guide mechanism between international trade and international logistics in Shandong province.

\subsection{Policy suggestions}

Based on the conclusion above and integrated Shandong's own development status, the paper raised three policy suggestions:

Firstly, as to macro-policy, Shandong province should make full use of congenital advantage such as geographical location, resource endowment and sufficient labor. Then, based on the strategic background of the flourish of Shandong Peninsula Blue Economic Zone, Shandong province should strengthen the link and interact with international trade and international logistics, and enact relevant policies to promote the development of international trade and international logistics. In order to standardize the order of the international trade market and construct the international logistics development environment, the concrete method including support policy of international logistics enterprise, establish and perfect the international logistics infrastructure and international logistics system, improve efficiency, reduce the intermediate process, and strengthen departments' coordination. Meanwhile, Shandong province should grasp the development opportunity with Japan and South Korea, with its unique geographical location and good open condition to vigorously attract foreign investment, optimize investment environment, introduce foreign advanced logistics management and technology experience, and expand domestic and foreign logistics strategic alliance, driving the development of international trade and international logistics to the largest extent in Shandong province.

Secondly, from the micro-construction aspect, Shandong province has superior location since it located in the northeast Asia ocean transport hub. Therefore, it should strengthen the international logistics infrastructure construction in bonded zones to ensure the easy access to highway, railway and maritime transportation, and realize regional economic integration to ensure the international multimodal transport. Meanwhile, Shandong should enhance the modernization of distribution park management process by making innovative reconstruction based on the existing infrastructure and setting up the internationalization of public information platform, as well as make full use of information technology and high-tech products improving the internationalization and efficiency of logistics operations in order to provide good hardware guarantee for the international trade in bonded area. About port construction, Shandong province should take the port of Qingdao for the center, coordinate with the port of Yantai, Weihai and Rizhao for common development to promote the integration of resources and realize the port area linkage. In the meantime, Shandong should increase port construction, expand radiating and driving function of ports, give full play to its own characteristics to avoid the "convergence" of port development. Finally, drive the construction of international logistics through the expansion of port economic hinterland, and promote the development of international trade in Shandong province.

There are lots of colleges, universities, scientific research institutions in Shandong province, and the scholars majoring in trade engineering have a firm background and professional. Therefore, to train more and better professional trade worker, Shandong province should aim to create a mode for integration of training and researching, learn advanced philosophy and training experience from abroad, and cooperate with international trade enterprises. To stimulate the development of international trade induced by Shandong province, Shandong province should develop a comprehensive, effective, creative policy based on the future development direction of Shandong Province free trade zone and by integrating of experienced advanced and fresh innovated logistics workers.

\section{References}

1. Q.C. Liu, "Discussing on the impact of international logistics on international trade", Jiangsu. Comm. Rev., vol.12. pp.60-62, 2011.

2. T.Jose, N.Owen, China's economic rise and its implications for logistics: The Australian case ,Trans. Pol., vol.16, pp. 224-231, 2009.

3. N.Owen, T.Jose, Causal Nexus between the Transport and Logistics Sector and Trade: The Case of Australia, Trans. Pol., vol.5, pp. 135-146, 2009.

4. C.C.Yang, The relationship between international trade and international logisticsc, Int'l Trade., vol.10, pp. 28-31, 2007.

5. Y.Y.Zhang,: A study of the relation develpopment between Sino-Thai mutual trade and logistics, 2011.

6. Y.Yue: Analysis of China-Japan international logistics impact on the bilateral trade, 2013.

7. M.L.Wang, B.L.Liu, Analysis on the influence factors of international logistics development in Tianjin Binhai New Area, Mod. Mgmt. Sci, vol.11, pp. 63-65, 2014.

8. L.Wang, Empirical Study on Relationship between Foreign Trade and Modern Logistics:Based on Shanghai Data from 1978 to 2008, Int'l Trade J., vol.1, pp. 59-65, 2010.

9. Y.L.Wang, J.Wang, Empirical Analysis on the Relationship between AquaticProduct Trade and Logistics in Taiwan, J. F N Univ: Soc. Sci. Ed., vol.5, pp. 50-55, 2011. 
10. X.L.Gao, F.R.Meng, Empirical Analysis on Relationship between GuangdongForeign Trade and International Logistics, Tech. Mgmt. Res., vol. 21, pp. 86-90, 2012.

11. Y.Kong, Empirical study on relationship between international logistics and international trade, J S Univ Technol: Soc. Sci. Ed., vol.4, pp. 335-341, 2010.

12. J.Devlin, P.Yee. Global Links to regional networks: Trade logistics in MENA countries, MENA Trade \& Investment in the New Economy, 2002.

13. M.P. Keane, S.E. Feinberg, Advances in Logistics and the Growth of Intra-Firm Trade:The Case of Canadian Affiliates of U.S. Multinationals, J. Ind. Econ., vol.4, pp. 571-632, 2007.
14. H.K. Nordås, E. Pinali, Logistics and Time as a Trade Barrier, OECD Trade Policy Papers, 2006.

15. P.Li, Research on the influence of logistics competitiveness on trade, Know. Econ., vol.8, pp. 129-130, 2010.

16. R.J.Chen, An empirical analysis of Shanghai port logistics and international trade development, Chin. Col. Econ., vol.1, pp. 124-125, 2010.

17. J.Y.Li, L.T.Sun, Empirical Analysis of Interaction between Yunnan Logistics Industryand International Trade Based on Granger-causal Test, Log. Tech., vol.13, pp. 242-244, 2013. 